\title{
KUALITAS CHICKEN NUGGET YANG DIFORTIFIKASI DENGAN TEPUNG KACANG KEDELAI UNTUK PENINGKATAN SERAT PANGAN (DIETARY FIBER)
}

\author{
Astria Mawati, E.H.B. Sondakh, J.A.D. Kalele*, R. Hadju
}

Fakultas Peternakan Universitas Sam Ratulangi Manado, 95115

\begin{abstract}
ABSTRAK
Penelitian ini bertujuan untuk mengetahui pengaruh fortifikasi tepung kacang kedelai terhadap peningkatan serat pangan (dietary fiber) produk chicken nugget. Daging yang digunakan untuk pembuatan nugget diambil bagian dada. Kacang kedelai digunakan sebagai bahan fortifikasi untuk pembuatan chicken nugget. Percobaan ini menggunakan rancangan acak lengkap dengan lima perlakuan yang terdiri dari perlakuan R0 level 0\% kacang kedelai dari komposisi daging basal 400 gr daging (0 gr kacang kedelai dan 400 gr daging), R1 level 5\% kacang kedelai dari komposisi daging basal (20 gr kedelai dan 380 gr daging) R2 level $10 \%$ kacang kedelai dari komposisi daging basal (40 gr kacang kedelai dan 360 gr daging), R3 15\% kacang kedelai dari komposisi daging basal (60 gr kacang kedelai dan 340 gr daging), R4 level 20\% kacang kedelai dari komposisi daging basal (80 gr kacang kedelai dan 320 gr daging). Setiap perlakuan dilakukan tiga kali ulangan. Apabila terdapat perbedaan yang nyata dalam analisis varian maka pembanding rata-rata dilakukan dengan menggunakan uji DMRT. Hasil penelitian menunjukkan bahwa fortifikasi dengan kacang kedelai pada daging ayam memberikan pengaruh yang signifikan terhadap daya mengikat air, dan kandungan serat pangan, sedangkan $\mathrm{pH}$ daging tidak signifikan. Kesimpulannya adalah tepung kacang kedelai 80 gram yang difortifikasi pada 320 gram daging ayam dapat
\end{abstract}

*Korespondensi (corresponding author)

Email: kalelejerry@yahoo.co.id digunakan untuk pembuatan chicken nugget karena dapat meningkatkan kandungan serat pangan (dietary fiber)

Kata kunci: nugget ayam, tepung kacang kedelai, serat pangan

\section{ABSTRACT}

THE QUALITY OF CHICKEN NUGGET FORTIFICATED BY SOYBEAN FLOUR ON INCREASING DIETARY FIBER. This research aimed to determine the effect of soy bean flour as fortification ingredient to increase dietary fiber products to chicken nuggets. The meat used for nuggets chicken was taken chest. Soybeans are used as a fortification ingredient for the product of chicken nuggets. This experiment using a completely randomized design with five treatments consisting of a treatment $\mathrm{R} 0$ level $0 \%$ of soybean of the meat composition of $400 \mathrm{~g}$ ( $0 \mathrm{~g}$ of soybean and $400 \mathrm{~g}$ of meat), R1 level of $5 \%$ of soybean of the meat composition ( $20 \mathrm{~g}$ soybean and $380 \mathrm{~g}$ of meat) R2 level of $10 \%$ of soy bean of the meat composition (40 $\mathrm{g}$ of soybean and $360 \mathrm{~g}$ of meat), R3 $15 \%$ of soy bean of the meat composition (60 $\mathrm{g}$ of soybean and $340 \mathrm{~g}$ of meat), R4 level $20 \%$ soybean of the meat composition ( $80 \mathrm{~g}$ of soybean and $320 \mathrm{~g}$ of meat). Each treatment was conducted three replications. If there was a difference of average in the analysis of variance then to DMRT test. The results showed that fortification with soy beans in chicken meat had a significant on the water holding capacity and fiber dietary, while 
the $\mathrm{pH}$ of the meat is not significant. The conclusion of this study that 80 grams of soy bean flour fortified in 320 grams meat can be used for the product chicken nuggets because it can increase the content of dietary fiber.

Keywords: chicken nugget, soybean flour, dietary fiber

\section{PENDAHULUAN}

Daging merupakan hasil peternakan yang mampu mencukupi kebutuhan gizi manusia.Daging mengandung sumber protein hewani yang bernilai tinggi, kaya protein, lemak, mineral dan vitamin serta zat-zat yang diperlukan tubuh. Namun demikian sisi kelemahan dari daging adalah mudah rusak dan dapat menimbulkan penyakit-penyakit degenatif ketika dikonsumsi tidak terkontrol. Menurut Soeparno (2005) daging dapat didefinisikan semua jaringan hewan dan produk hasil pengolahan jaringan-jaringan tersebut yang sesuai untuk dimakan. Organ-organ misalnya hati, ginjal, otak, paru-paru, jantung, limpa, pangkreas, dan jaringan otot termasuk dalam definisi ini.

Pemilihan pengkonsumsian daging pada masyarakat lebih banyak pada hasil ternak unggas, terutama ayam broiler. Daging ayam broiler adalah bahan makanan yang mengandung gizi tinggi, memiliki rasa dan aroma yang enak, tekstur yang lunak dan harga relatif murah. Hal ini yang membuat ayam broiler hampir disukai semua orang. Komposisi kimia daging ayam terdiri dari protein $18,6 \%$, lemak $15,06 \%$, air $65,95 \%$, dan abu $0,79 \%$ (Suradi 2006).

Terdapat banyak produk-produk olahan daging yang sangat disukai oleh masyarakat, diantaranya adalah chicken nugget. Produk olahan daging seperti nugget merupakan makanan yang sangat popular di Indonesia. Pada umumnya nugget berbentuk balok, namun saat ini nugget makin banyak variatif. Nugget dibuat dari daging yang digiling halus dicampur dengan bumbu-bumbu, bahan pengisi (filler) dan bahan tambahan lainnya kemudian dibentuk, dikukus setelah itu dicelupkan pada kuning telur kemudian ditaburi pada tepug pati digulingkan lagi dengan kuning telur selesai itu digulingkan pada tepung roti terakhir digoreng pada suhu $180^{\circ} \mathrm{C}$.

Penganekaragaman produk-produk hayati sebagai extender untuk meningkatkan kualitas produk olahan daging semakin berkembang dewasa ini.Substitusi dengan bahan-bahan nabati cukup popular karena mempunyai beberapa keunggulan yang bisa dimanfaatkan oleh produk olahan daging. Keunggulan yang bisa diambil melalui substitusi bahan hayati antara lain dapat meningkatkan gizi serta meningkatkan nilai kesukaan dari produk olahan tersebut. Pemanfaatan produk nabati 
yang digabungkan dengan produk olahan daging seperti nugget menjadi sisi menarik untuk diteliti. Produk nabati yang cukup terkenal mempunyai nilai gizi tinggi adalah tepung kedelai. Komposisi kedelai terdiri dari protein 32,2 gram, serat 4,3 gram, lemak 17,7 gram, air 10,2 gram dan energi 400 kkal (Adisarwoto, 2007). Kedelai banyak digunakan dalam berbagai pangan, seperti tempe, tahu, kecap dan kecambah. Nutrisi yang terkandung pada tepung kedelai dapat dimanfaatkan dalam menambah nilai gizi yang terkandung pada produk nugget. Sisi keunggulan dari tepung kedelai yang menjadi menarik untuk diteliti karena tepung kedelai mengandung serat yang tinggi.

Daging ayam broiler sebagai bahan utama nugget memiliki kandungan lemak yang cukup tinggi. Konsumsi lemak berlebih dapat membahayakan konsumen. Lemak dapat tertimbun dalam tubuh sehingga dapat menyebabkan macam penyakit seperti stroke, jantung, koroner, obesitas dan lain sebagainya, oleh karena itu lemak pada produk nugget harus diimbangi dengan adanya kandungan serat kasar pada tepung kedelai. Lemak yang terserap tubuh dapat dibatasi dengan penambahan tepung kedelai. Fortifikasi tepung kedelai diharapkan menghasilkan produk nugget yang mengandung serat, sehingga produk ini dapat dijadikan sumber pangan kesehatan.

\section{MATERI DAN METODE PENELITIAN}

\section{Materi Penelitian}

Bahan.

Bahan yang digunakan untuk membuat nugget dengan substitusi tepung kedelai terdiri dari daging ayam broiler, tepung kedelai, tepung tapioka, serta bumbu-bumbu yang terdiri dari bawang putih, merica bubuk, garam, es, buffer $\mathrm{pH}$ 7 untuk uji $\mathrm{pH}, \mathrm{H}_{2} \mathrm{O}$, aquades, $\mathrm{NaOH}$, $\mathrm{H}_{2} \mathrm{SO}_{4} 1,25 \%$.

Alat

Peralatan yang digunakan untuk membuat nugget ayam yaitu penggilingan blender, timbangan analitik, panci, pisau, kompor, gas, oven, lemari es, pendingin, timbangan digital, carper press uji daya mengikat air, dua lempengan kaca dengan ketebalan berbeda, pemberat, plastik transparan, whatman 41, spidol, $\mathrm{pH}$ meter, mangkok/wadah, selongsong serat dan rangkaian alat hidrolisis untuk uji serat.

\section{Metode Penelitian}

\section{Rancangan Percobaan}

Penelitian ini menggunakan Rancangan Acak Lengkap (RAL) dengan 5 perlakuan dan 3 ulangan. Untuk pengujian $\mathrm{pH}$, daya mengikat air dan kadar serat kasar, terdiri dari atas perlakuan yaitu: R0 = Nugget ayam tanpa fortifikasi tepung kedelai 
$\mathrm{R} 1$ = Nugget ayam dengan fortifikasi tepung kedelai $5 \%$ dari berat daging ayam R2 = Nugget ayam dengan fortifikasi tepung kedelai $10 \%$ dari berat daging ayam R3 = Nugget ayam dengan fortifikasi tepung kedelai $15 \%$ dari berat daging ayam R4 = Nugget ayam dengan fortifikasi tepung kedelai $20 \%$ dari berat daging ayam

\section{Pembuatan Tepung Kedelai}

Tepung kedelai dapat dibuat dengan cara 1) $1 \mathrm{~kg}$ kedelai disortasi untuk memilih kedelai yang baik, membuang benda asing dan kedelai yang rusak atau pecah, 2) Kemudian kedelai dicuci bersih, 3) kedelai ditiriskan dan dikeringkan dengan dijemur atau menggunakan oven dengan suhu $50^{\circ} \mathrm{C}$ selama 12 jam dan digiling halus dan diayak dengan ayakan 60 mesh sehingga diperoleh tepung kedelai yang halus.

\section{Pembuatan Nugget}

Pembuatan nugget ayam dengan substitusi tepung kedelai dilakukan dengan empat level tepung kedelai yang berbeda yaitu $0,5,10,15$ dan 20\%. Daging ayam broiler yang telah dipisahkan dari tulang dan kulit, dipotong kecil-kecil kemudian giling sampai halus. Bahan yang terdiri dari bawang putih, bawang merah, penyedap, susu bubuk merica, es, garam, dan tepung tapioca campur. Kemudian daging ayam yang telah digiling campur dengan tepung kedelai, tapioka. Adonan setelah homogen cetakdalam wadah aluminium, kukus selama 30 menit dengan suhu $60^{\circ} \mathrm{C}-70^{\circ} \mathrm{C}$ kemudian potong.

Tabel 1. Formulasi Nugget Ayam Dan Fortifikasi Tepung Kedelai Pada Level Berbeda.

\begin{tabular}{lccccc}
\hline \multirow{2}{*}{\multicolumn{1}{c}{ Bahan }} & \multicolumn{5}{c}{$\begin{array}{c}\text { Level fortifikasi tepung kedele dari } \\
\text { komposisi daging basal }\end{array}$} \\
\cline { 2 - 6 } & $\mathrm{RO}$ & $\mathrm{R} 1$ & $\mathrm{R} 2$ & $\mathrm{R} 3$ & $\mathrm{R} 4$ \\
\hline Daging ayam broiler (g) & 400 & 380 & 360 & 340 & 320 \\
Tepung kedele (g) & 0 & 20 & 40 & 60 & 80 \\
Es batu (g) & 65 & 65 & 65 & 65 & 65 \\
Tapioka (g) & 150 & 150 & 150 & 150 & 150 \\
Susu (g) & 27 & 27 & 27 & 27 & 27 \\
penyedap (g) & 15 & 15 & 15 & 15 & 15 \\
Merica (g) & 3 & 3 & 3 & 3 & 3 \\
Bawang putih (g) & 22 & 22 & 22 & 22 & 22 \\
\hline \multicolumn{1}{c}{ Jumlah (g) } & 682 & 682 & 682 & 682 & 682 \\
\hline Minyak goreng (sendok makan) & 3 & 3 & 3 & 3 & 3 \\
Kuning telur (butir) & 2 & 2 & 2 & 2 & 2 \\
\hline
\end{tabular}


Nugget ayam yang dihasilkan digunakan untuk uji kualitas yang terdiri dari uji $\mathrm{pH}$, daya mengikat air, keempukan dan serat masing-masing. Setiap perlakuan tiga kali replikasi. Formulasi nugget ayam dengan substitusi tepung kedelai secara lengkap tercantum dalam Tabel 1.

\section{Variabel yang diamati}

\section{Pengukuran nilai pH}

Sampel nugget ayam seberat $10 \mathrm{~g}$ dicacah, ditambah $10 \mathrm{ml}$ aquades, diaduk homogen. Nilai $\mathrm{pH}$ diukur dengan $\mathrm{pH}$ meter, yang sebelumnya telah dikalibrasi dengan larutan buffer $\mathrm{pH}$ 7. Pengukuran nilai $\mathrm{pH}$ dilakukan sebanyak lima kali kemudian hasilnya dibuat rataan.

\section{Pengukuran daya mengikat air}

Metode yang digunakan adalah metode Hamm (Soeparno, 2005). Sampel nugget seberat 0,3 gram diletakan diatas kertas saring bebas air diantara 2 plat kaca dan diberi beban seberat $35 \mathrm{~kg}$ selama 5 menit. Area yang telah tertutup sampel daging yang telah menjadi pipih pada kertas saring dan luas area basah di sekelilingnya ditandai dan dihitung (luas area basah, digambar pada kertas grafik).

$$
\mathrm{H}_{2} \mathrm{O}(\mathrm{mg})=\frac{\text { luas area basah }(\mathrm{cm} 2)}{0,0948}-8
$$

Kadar air bebas $=\frac{\operatorname{mgH} 20}{\text { Berat sampel }} \times 100 \%$ $\mathrm{DIA}=\mathrm{KAT}-\mathrm{KAB}$

\section{Uji kadar serat kasar}

Analisis kandungan serat kasar dilakukan dengan menggunakan fiber cap. Prinsip analisis sesuai dengan Sudarrmaji et al. (2003). Serat kasar dapat dihitung dengan cara bahan sampel dihaluskan dan dimasukan ke tabung selongsong, kemudian ditambah $450 \mathrm{ml}$ larutan $\mathrm{H}_{2} \mathrm{SO}_{4}$ $1,25 \%$ dipanaskan selama dua jam. Selongsong yang telah dipanaskan selama dua jam kemudian dicuci diair mengalir selama lebih kurang lima menit untuk menghilangkan asam. Sampel ditambah kembali dengan $450 \mathrm{ml} \mathrm{NaOH} \quad 1,25 \%$ kemudian dipanaskan selama dua jam, dicuci kembali dengan air mengalir selama lebih kurang lima menit untuk menghilangkan basa, kemudian dioven pada suhu $110^{\circ} \mathrm{C}$ selama lima jam, lalu ditimbang. Penimbangan selanjutnya satu jam sekali hingga berat residu konstan. Berat residu merupakan berat serat kasar.

Perhitungan:

$\underline{\text { (Berat selongsong + sampel konstan)-Berat selongsong konstan }}$ x $100 \%$

\section{Analisis Data}

Data penelitian yang terdiri dari $\mathrm{pH}$, daya mengikat air, dan serat kasar dianalisis menggunakan analisis variansi dengan rancangan acak lengkap pola searah dan apabila ada perbedaan rata-rata diuji 
dengan Duncan"s New Multiple Range Test (Steel dan Torrie, 1990).

\section{HASIL DAN PEMBAHASAN}

Hasil penelitian pengaruh fortifikasi tepung kedelai pada produk nugget ayam terhadap parameter $\mathrm{pH}$, daya mengikat air dan kandungan serat kasar produk dapat dilihat pada Tabel 2.

\section{Derajat Keasaman (pH)}

Hasil penelitian mengenai penambahan tepung kedelai sebagai bahan fortifikasi pada produk nugget ayam seperti tercantum pada Tabel 2. Hasil analisis statistik tidak terdapat perbedaan nilai $\mathrm{pH}$ pada produk nugget yang difortifikasi dengan tepung kedelai. Pemberian tepung kedelai sampai dengan level 20\% yakni daging 320 gram dan 80 gram tepung kedelai secara statistik masih sama dengan produk nugget tanpa penambahan tepung kedelai. Nilai $\mathrm{pH}$ pada penelitian ini berkisar antara 6,3-7,0. Komponen daging pada pembuatan nugget merupakan komponen terpenting dan terbesar dalam komposisi pembuatan nugget daging ayam baik yang difortifikasi dengan tepung kedelai maupun tidak difortifikasi dengan kedelai dan diduga hal ini menjadi penyebab nilai $\mathrm{pH}$ tidak berbeda. Nilai $\mathrm{pH}$ nugget daging ayam sangat ditentukan oleh pH daging ayam. Pada penelitian ini daging memiliki porsi terbesar sampai 400 gram, sementara tepung kedelai sebagai bahan fortifikasi memiliki porsi sebesar 80 gram (20\%) pada Tabel 1.

Perlakuan pencincangan daging, penggilingan, dan pembuatan adonan dapat menyebabkan nilai $\mathrm{pH}$ turun. Proses penggilingan akan menyebabkan kerusakan pada ikatan-ikatan protein daging yang akan mempermudah perubahan kedudukan ion $\mathrm{H}^{+}$dan $\mathrm{OH}$ saat dilakukan pemasakan. Daging secara umum mempunyai kisaran pH 5,3 sampai 6,0. Hasil penelitian ini menunjukan bahwa, $\mathrm{pH}$ nugget secara berturut-turut adalah7,0, 6,9, 6,8, 6,7 dan 6,3 konversi tepung kedelai 0\%,5\%, 10\%, $15 \%$ dan $20 \%$. Nilai $\mathrm{pH}$ inirelatif lebih tinggi dari $\mathrm{pH}$ daging. Peningkatan $\mathrm{pH}$ nugget ayam dibandingkan dengan $\mathrm{pH}$ daging oleh karena nugget merupakan produk yang telah melalui proses pemasakan. Soeparno (2005) menyatakan bahwa pemasakan akan menyebabkan penurunan gugus asidik sehingga titik isoelektrik meningkat, juga disebabkan karena penambahan garam pada pembuatan nugget. Lebih jauh, pH ultimat daging, yaitu $\mathrm{pH}$ yang tercapai setelah glikolisis otot habis atau glikolisis tidak lagi sensitive oleh serangan-serangan enzim glikolitik, normalnya adalah 5,4-5,8. Laju glikolisis post mortem pada daging menyebabkan terurainya glikogen menjadi glukosa, glukosa akan mengalami penguraian oleh 
Tabel 2. Rataan Nilai Ph, Daya Mengikat Air Daging Dan Kandungan Serat Kasar Produk Nugget Ayam Yang Difortifikasi Dengan Tepung Kedelai Pada Level Yang Berbeda.

\begin{tabular}{|c|c|c|c|c|c|}
\hline \multirow{2}{*}{ Variabel } & \multicolumn{5}{|c|}{ Level substitusi tepung kedelai dari komposisi daging basal } \\
\hline & $0 \%$ & $5 \%$ & $10 \%$ & $15 \%$ & $20 \%$ \\
\hline $\mathrm{pH}^{\mathrm{ns}}$ & $7,0 \pm 0,02$ & $6,9 \pm 0.03$ & $6,8 \pm 0,54$ & $6,7 \pm 0,57$ & $6,3 \pm 0.28$ \\
\hline Daya mengikat air & $49,39 \pm 0,33^{\mathrm{a}}$ & $51,72 \pm 1,41^{\mathrm{ab}}$ & $52,51 \pm 2,46^{\mathrm{b}}$ & $53,41 \pm 1,56^{\mathrm{b}}$ & $54,39 \pm 1,36^{\mathrm{b}}$ \\
\hline Serat kasar & $0,13 \pm 0,011^{\mathrm{a}}$ & $0,15 \pm 0,005^{\mathrm{b}}$ & $0,16 \pm 0,15^{\mathrm{b}}$ & $0,17 \pm 0,006^{c}$ & $0,19 \pm 0,006^{\mathrm{d}}$ \\
\hline $\begin{array}{r}\text { Keterangan: Kandu } \\
\text { (dagin } \\
\text { kedele } \\
\text { tepun } \\
\text { Super }\end{array}$ & $\begin{array}{l}\text { ), kandungan } \\
\text { ai } 20 \% \text { (dagi } \\
\text { ada baris van }\end{array}$ & $\begin{array}{l}\text { ung kedele } 15 \\
20 \text { gr, tepung } \\
\text { ma menuniukk }\end{array}$ & $\begin{array}{l}\text { (daging } 340 \\
\text { lelai } 80 \text { gr). }\end{array}$ & $\begin{array}{l}\text { gr), kandung } \\
\text { delai } 10 \%(\mathrm{da} \\
\text { tepung kedela } \\
(\mathrm{P}<0.05)\end{array}$ & $\begin{array}{l}\text { tepung kedelai } \\
\text { ig } 360 \text { gr, tep } \\
50 \text { gr), kandun }\end{array}$ \\
\hline
\end{tabular}

enzim-enzim menjadi asam laktat (Dewi, 2012). Menurut Dewi (2006) bahwa asam laktat daging sangat mempengaruhi nilai $\mathrm{pH}$ daging, dimana daging dengan asam laktat yang tinggi akan mempunyai $\mathrm{pH}$ daging yang rendah.

Pada penelitian ini ada indikasi bahwa kandungan lemak menurun seiring dengan penambahan perlakuan. Penurunan kandungan lemak menyebabkan terjadi penurunan $\mathrm{pH}$. Terdapat korelasi antara kandungan lemak produk dengan nilai $\mathrm{pH}$ produk tersebut. Semakin menurun kandungan lemak, mengakibatkan nilai $\mathrm{pH}$ menurun (Lesson dan Summers, 1980).

\section{Daya Mengikat Air}

Hasil analisis statistik menunjukan bahwa nugget ayam dengan fortifikasi tepung kedelai dengan level yang berbeda memberikan perbedaan yang nyata terhadap nilai daya mengikat air nugget ayam (Tabel 2). Terdapat perbedaan nilai daya mengikat air $(\mathrm{P}<0,05)$ pada produk nugget yang difortifikasi dengan tepung kedelai. Rataan nilai daya mengikat nugget ayam dengan substitusi tepung kedelai pada level $0 \%, 5 \%, 10 \%, 15 \%$ dan $20 \%$ masing - masing adalah 49,39\%, 51,72\%, 52,51\%, $53,41 \%$ dan $54,39 \%$. Pengujian hasil nilai rataan menunjukkan bahwa fortifikasi tepung kedelai mulai $10-15 \%$ nyata lebih tinggi nilai daya mengikat dibandingkan dengan tanpa tepung kedelai (0\%). Penggunaan tepung kedelai $10 \%$ mampu meningkatkan nilai daya mengikat air sebesar $6,31 \%$ dan setelah dinaikkan lagi tepung kedelai sampai dengan $20 \%$ terjadi peningkatan daya mengikat air sebesar $10,12 \%$.

Peningkatan nilai daya mengikat air diduga karena tepung kedelai mempunyai kandungan protein yang tinggi sehingga mampu mengikat air. Menurut Soeparno 
(2005), daya mengikat air daging memegang peran yang sangat besar pada pembuatan produk daging proses, misalnya, selama proses pemanasan, penggilingan, pencampuran bahan, atau dalam proses emulsifikasi menjadi produk daging proses. Kehilangan berat selama prosesing daging, sebagiannya adalah evaporasi air pada umumnya.pH sekitar 5,8 atau lebih akan menaikan kemampuan menahan air. Menurut Lawrie (1996), pH sangat berpengaruh terhadap daya mengikat air daging. Nilai $\mathrm{pH}$ dalam penelitian ini, hasilnya adalah berbeda tidak nyata, semakin rendah $\mathrm{pH}$ maka semakin tinggi daya mengikat airnya, sehingga air dalam nugget ayam juga terikat kuat oleh protein tepung kedelai selain terikat dengan protein daging. Daging dan tepung kedelai merupakan komponen yang dapat mengikat air dalam nugget ayam. Daging mempunyai kemampuan untuk mengikat airnya atau air yang ditambahkan selama ada pengaruh kekuatan dari luar. Faktor-faktor yang mempengaruhi daya mengikat air nugget, antara lain $\mathrm{pH}$, pemasakan atau pemanasan, macam otot, jenis otot, dan lemak intramuscular daging yang digunakan (Soeparno, 2005).

\section{Soeparno (2005) menyatakan} bahwa daya mengikat air mengalami perubahan besar dengan pemanasan pada temperature $60^{\circ} \mathrm{C}$ karena protein sarkoplasmik hampir mengalami denaturasi sempurna karena pemasakan. Suhu tinggi meningkatkan denaturasi protein dan mempengaruhi daya mengikat air. Jumlah air yang terkandung dalam nugget tergantung dari banyaknya air yang ditambahkan dalam adonan dan proporsi daging yang digunakan (Triatmojo, 1992). Daya mengikat air juga dipengaruhi oleh air dan bumbu sebagai bahan tambahan penyusun nugget ayam. Pada penelitian ini air dan bumbu-bumbu yang digunakan pada setiap level substitusi memiliki presentase yang sama.

$$
\text { Pada penelitian ini terjadi }
$$
pengurangan jumlah lemak seiring dengan perlakuan yang diberikan oleh karena terjadi pengurangan porsi daging pada pembuatan nugget. Edwars (1981), menyatakan bahwa kadar lemak mempunyai kolerasi negatif dengan kadar protein. Penurunan lemak daging menyebabkan kenaikan jumlah protein daging (Purnamasari et al., 2013). Meningkatnya protein pada pada produk daging pada penelitian ini mengakibatkan daya ikat air meningkat. Linawati (2006) menyatakan bahwa daya ikat air dipengaruhi protein daging terutama protein miofibril dan sarkoplasma. Korelasi antara protein daging dan lemak daging terhadap daya mengikat air pernah diteliti oleh Oktoviani (2002) yakni penambahan VCO dalam pakan broiler menyebabkan penurunan kandungan lemak daging dan 
meningkatnya protein daging sehingga terjadinya peningkatan daya mengikat air daging.

\section{Karakteristik Serat Kasar}

Hasil analisis penelitian nugget ayam yang difortifikasi dengan tepung kedelai menunjukan bahwa substitusi tepung kedelai pada level $15 \%$ dapat meningkatkan rataan kandungan serat kasar pada nugget ayam $(\mathrm{P}<0,05)$. Perlakuan substitusi tepung kedelai kedalam nugget ayam pada level $0 \%$ mengandung rataan serat kasar sebanyak 0,13\%. Perlakuan fortifikasi tepung kedelai secara simultan terjadi peningkatan pada level 5\% meningkatkan rataan kandungan serat kasar sebanyak $0,15 \%$, pada level $15 \%$ fortifikasi tepung kedelai kandungan serat kasarnya 0,17\%, dan pada level 20\% kandungan serat kasar sebanyak $0,19 \%$.

Hasil penelitian yang berbeda nyata dapat disebabkan karena tepung kedelai yang disubstitusikan kedalam nugget ayam banyak mengandung serat kasar, Menurut Adisarwoto (2007), kandungan serat pada tepung kedelai adalah 4,3 gram per 100 gram tepung kedelai. Pada penelitian ini, kandungan serat kasar pada nugget ayam yang difortifikasi tepung kedelai terus meningkat, semakin tinggi jumlah tepung kedelai yang difortifikasi kedalam nugget ayam maka semakin tinggi pula kandungan serat kasar pada nugget ayam.
Serat kasar yang terkandung dalam nugget ayam dapat dijadikan indeks kandungan serat pangan dalam nugget ayam. Pada dasarnya kandungan serat pangan lebih tinggi dari serat kasar. Selama proses pemanasan serat kasar tidak mengalami perubahan karena serat kasar hanya mampu terdegradasi oleh asam kuat dan basa kuat selama 30 menit. Kandungan utama pada serat kasar adalah selulosa. Pada proses pencernaan, selulosa tidak dicerna. Selulosa menyediakan bahan pengenyang dan bahan kasar pada pangan yang membantu memelihara daya gerak dan seluruh kesehatan pencernaan (Suhardjo et al., 2006). Menurut Budianta et al. (2001) hal ini disebabkan adanya serat pangan yang berperan sebagai pengikat air. Darojat (2010) menjelaskan bahwa serat pangan yang memiliki luas permukaan yang sangat besar dan struktur yang berbentuk kapiler sehingga memiliki kemampuan untuk menyerap air yang tinggi.

\section{KESIMPULAN}

Tepung kedelai 80 gram (20\%) yang difortifikasi pada 320 gram daging ayam dapat digunakan untuk pembuatan chicken nugget karena dapat meningkatkan kandungan serat pangan (dietary fiber). 


\section{DAFTAR PUSTAKA}

Adisarwoto, T. 2007. Budidaya dengan Pemupukan yang Efektif dan Pengoptimalan Peran Bintil Akar Kedelai. Penebar Swadaya, Depok

Budianta, T.D.W., H. Purnama dan Natalia. 2001. Pembuatan dendeng giling daging kambing yang diperkaya dengan buah nangka muda (Artocorpus heterophyllus Lamk). Buletin Peternakan. Edisi Tambahan, Hal: 194-204

Dewi, S.H.C. 2006. Pengaruh pemberian gula, insulin dan lama istirahat sebelum pemotongan pada domba setelah pengangkutan terhadap kualitas kimia daging. Prosiding Seminar Nasional, UNDIP Semarang.

Dewi, S.H.C. 2012. Populasi mikroba dan sifat fisik daging sapi beku selama penyimpanan.AgriSains Vol.3 (4): $1-12$

Darojat, D. 2010. Manfaat penambahan serat pangan pada produk daging olahan. Jurnal Pangan dan Gizi Vol 1(2). Food Review 5(7):52-53

Edwards, H.M. Jr. 1981. Carcass composition studies. 3. Influence of age, sex and calorie protein contents of the diet on carcass composition of Japanese quail. Poultry Sci. 60: 2506-2512.

Lawrie, R. A. 1996. Ilmu Daging Diterjemakan oleh Aminudin Parakkasi A. Penerbit Universitas Indonesia Press, Jakarta.

Leeson and J. D. Summer. 1980. Production and carcass characteristic of the broiler chicken. Poultry Sci. 59:786-798.

Linawati. 2006. Kadar Protein kolagen dan hubungan dengan kualitas daging sapi PO. Laporan Penelitian. Universitas Gadjah Mada. Yogyakarta

Oktaviana, D., Zuprizal, E. Suryanto. 2009. Pengaruh penambahan ampas virgin coconut oil dalam ransum terhadap performan dan produksi karkas ayam broiler. Buletin Peternakan 34(3): 159-164

Purnamasari, E., Mardiana, Y. Fazila, W.H.Z. Nurwidada, D. Febrina. 2013. Sifat fisik dan kimia daging sapi yang dimarinasi jus buah pinang (Areca catechu L.). Prosidding. Seminar Nasional Teknologi Peternakan dan Veteriner. 216-226

Soeparno, 2005. Ilmudan Teknologi Daging. Gadjah Mada University. Cetakan keempat. Gadjah Mada University Press.Yogyakarta.

Sudarmadji, S. 2003. Mikrobiologi Pangan. PAU Pangan dan Gizi UGM. Yogyakarta.

Suhardjo. 2006. Pangan, Gizi, dan Pertanian. Jakarta: Universitas Indonesia.

Suradi, K. 2006. Perubahan sifat fisik daging ayam post portem selama penyimpanan suhu ruang. Ilmu Ternak 6(1): 23-27.

Triatmojo, S. 1992. Pengaruh pergantian daging sapi dengan daging kerbau, ayam dan kelinci terhadap kualtas fisik nugget. Buletin Peternakan 16:63-71. 